\title{
Metropolitan Coordination in Mexico
}

\author{
Alberto Arellano Ríos \\ El Colegio de Jalisco, Zapopan, Mexico \\ Email: aarellano@coljal.edu.mx , betoarellano14@hotmail.com
}

Received 20 January 2015; accepted 1 February 2015; published 5 February 2015

Copyright (C) 2015 by author and Scientific Research Publishing Inc.

This work is licensed under the Creative Commons Attribution International License (CC BY).

http://creativecommons.org/licenses/by/4.0/

c) (i) Open Access

\begin{abstract}
This paper reflects the theme of metropolitan coordination in Mexico. The Metropolitan phenomenon has been established as an urbanely complex and social reality. In this sense, this paper contextualizes this phenomenon in Mexico, and public policies in metropolitan areas are designed and formulated. Finally, it is that the problem is intergovernmental coordination so questions of institutional design than the subjects of planning or land use must be considered more.
\end{abstract}

\section{Keywords}

Metropolitan Coordination, Metropolitanarea, Institutional Design

\section{Introduction}

The intergovernmental coordination is the institutional instrument that Governments in Mexico have to manage and solve problems in common. Different areas or matters of policy have origin and sustenance in the political Constitution of the Mexican States. The issues of public policy that arises among the theme of urban centers, are concurrent powers. This area of politics stands in the academic and political field that speaks of metropolitan coordination as real and close issues to manage and govern the areas or metropolitan areas of the country.

On the theme of metropolitan coordination there is enormous complexity, because multiple processes converge on it. This forces to discuss and clarify the nature of the Metropolitan phenomenon and the problem of metropolitan coordination as two phases of a problem of urban policy. To do so, we should be recognized that the urbanization is a sociological reality that shrinks a multiplicity of social, economic and urban problems. This determines that this policy issue is inserted into the government agenda and is designed and implemented in various public policies to address them.

Based on the above, this text outlines some ideas about metropolitan coordination. This document consists of three sections. In the first it ponders the Metropolitan phenomenon as the reality prevailing social and urban in Mexico. Policies that in terms of metropolitan areas are designed and formulated are then contextualized. Finally, is that the problem is intergovernmental coordination so it should be considered more questions of institutional design? 


\section{Metropolitan Phenomenon}

As is already mentioned a fundamental starting point is to differentiate the Metropolitan phenomenon of the Metropolitan problem. The first one referred to the urban growth and its various socioeconomic dynamics; while the second focused on locating and understanding the problem as a matter of public policy ${ }^{1}$.

The previous approach there is a basic distinction that is very important to emphasize. On the one hand are those who go to the study of the Metropolitan phenomenon in Mexico. This perspective analyzes and studies the problem as sociological reality and becomes the subject of governance and metropolitan policies to conclude that the root of their problems is in planning and management. This determines the answer to the problem of the field or as a technical issue. On the other hand, are those who argue, and myself in them, that the problem is not technical but political? This is because the problem is derived from the design and the system of political organization of the Mexican State. Seen the matter as well, the analysis and study are aimed at management, cooperation and intergovernmental coordination.

Of course the above distinction is analytical. Not only is there a social and urban against another government perspective. But that this differentiation determines not only a great approach or perspective, but the "focus" of the solution. It is true that both positions are not mutually exclusive but it is necessary to stress that each one has its own logic. He explained to me. Before it must be emphasized that the problem takes on shades to the rich and large municipal mosaic, but in municipalities that begin at the Metropolitan crossing, and given the institutional characteristics of their town councils, the solution to the problem is more institutional than technical. i.e., that urban and metropolitan municipalities can solve the technical part in terms of planning and land use planning, but at the end of account noticed that the problem is political: i.e., the problem lies in decision making. And the best example is the Metropolitan Area of Guadalajara (see Arellano \& Ortiz, 2013; Arias, 2013).

But by focusing on metropolitan phenomenon, and as an exercise in contextualization, recently we must recognize the public policies of the issue of metropolitan areas in territorial court. On the agenda of the Mexican State, and specifically of its instances of planning and who deliver and manage financial resources, this subject has been established. The importance of metropolitan areas policy has been instituted in the speech of the Government when, for example, it is mentioned that these are "the engines of the country's development" by concentrating large investments and existing skilled labor, as well as the necessary infrastructure for the development of economic activities. Its importance is such that it has been quantified in these urban areas concentrates $75 \%$ of the gross domestic product (Sedesol-Conapo-Inegi, 2007).

However, by principle of account, it should be emphasized that today the majority of the Mexican population is urban, i.e. living in the cities. In Mexican history, the twentieth century was the century of urbanization when some cities grew sharply. For example Mexico, Guadalajara and Monterrey. However, since 1990 we witness to the phenomenon of the urbanization. This reality placed Mexico, and based on the criteria of Sedesol, Conapo and Inegi (2010), that in the year of 2010, there were 59 metropolitan areas to the length and breadth of the country. The main feature of the Metropolitan phenomenon, as well as urbanization and other socio-economic processes, is that at least two municipalities are persisted in the city. And from the administrative point of view, institutional fragmentation occurs: an evil to manage and govern these cities; but given the institutional design of the federal system, this only has referred the coordination or intermunicipal associations to make them controllable (Arellano, 2013). Hence, from a public policy perspective, the challenge perspective is to take into account these institutional issues but focuing them on what strategies and public policy programs could be implemented in specific areas ${ }^{2}$.

\footnotetext{
${ }^{1}$ In this respect it should be noted that the debate on how to govern and manage the metropolitan areas is located between two positions; on the one hand, they are the defenders of the free municipality and, on the other hand, those who seek the establishment of metropolitan and regional governments. However, so far the coordination and intermunicipal associations are formal mechanisms allowing the constitutional design for governing this urban area (see Arellano, 2013). On the first slopes are authors in this aspect are the works of authors such as Luis Unikel, Alfonso Iracheta, Jaime Sobrino, Maria Eugenia Salar, Boris Graizbor, Carlos Garrocho, Socorro Arzaluz and Alicia Ziccardi. While on the second side are authors like this aspect are authors such as Vicente Ugalde, Leticia Santín del Rio, Carlos Zentella, Antonio Sánchez Bernal, Alberto Arellano, Roberto Arias, Xavier Ferreira, María Cadaval and Luis Caramés.

${ }^{2}$ By way of clarifying the problem to a region such as the Mexican West Center, it should be noted that in this area of the country, there are ten metropolitan areas. Guadalajara is of course, and following a model of interaction and functional structure of city, the regional center network (Garrocho, 2012: 137). Of these ten metropolitan areas, Jalisco would have four, as well as Guadalajara, Ocotlán and Puerto Vallarta, Manzanillo when one considers that this is built considering the Jalisco town of Cihuatlan's. Thus, there are three Interstate metropolitan areas in the region, and two are in Jalisco: the metropolitan area of Puerto Vallarta Jalisco and Nayarit, and the metropolitan area of Manzanillo Colima and Jalisco. Other Interstate metropolitan area is La Piedad-Penjamo between the States of Michoacan and Guanajuato. While other michoacana metropolitan area is the Zamora-Jacona. Cases require entering them and much work to be done but it is necessary to leave the appearance of the urban context to carry institutional reflection.
} 


\section{Policies and Metropolitan Areas: The Metropolitan Problem}

For many the issue of metropolitan areas undergoes a fashion to that are new and serious in which the Mexican state concentrates on planning policies, but at the expense of other policy areas, for example, regional policies. These are topics of agenda Government that since then the academic community makes his consciously or unconsciously. However, in planning exercises that recently emerged in dependencies as Secretary of Social Development (Sedesol) and the national population Council (Conapo), as well as from the federal level there are "metropolitan funds", are causing both positive and negative incentives. Some municipalities in the scene are questioning or forcing specified academic, legal and institutional what is meant by area and metropolitan area.

Although the definition and delimitation, commonly followed and accepted is the elaborate by Conapo and Sedesol, jointly with the National Institute of statistics, geography and Informatics (Inegi), which says that a metropolitan area is "the set of two or more municipalities where lies a city of 50,000 inhabitants, whose urban area, functions and activities go beyond the limit of the municipality that originally contained" (Garrocho, 2007: 21), for many it is not satisfactory. This is so because the debate that concluded he continues with greater intensity and some Councils are trying to with straitjacket follow it.

Federal agencies considered three criteria to conform the metropolitan areas in the country as follows: 1) a "central municipality" in which municipalities that share an intermunicipal conurbation and whose population altogether amounts to 50 thousand or more habitants; 2) a metropolization which includes foreign municipalities defined based on statistical and geographical criteria; and 3) an urbanization based on criteria of planning and urban policy (2007: 21-24).

Now, if the concept of metropolitan area is used in the field of planning, various federative entities choose other criteria or elements to constitute an area or metropolitan region. The topic by defining and specifying the urban areas is one minor matter. So the definitions are among the field of planning and in legal terms that emphasize the intergovernmental coordination. The question of the definition is important for the institutional implications and political avenues that municipal governments in Mexico have to deal with them. It should be noted that in the country there are isolated actions and General where there is still no common and basic consensus. Thus there are, in addition to Jalisco, other State laws in the area of metropolitan areas and at the federal level (see Arellano, 2012: 33-42). In addition the metropolitan affairs do not exist in the federal constitution, and the nearest idea is conurbation.

The incentive of accessing financial resources by councils forced to have clarity on this issue, because in practice, local governments are putting between said emerging responses to different bodies and institutions are developing. More than precision in laws and instances of political actors planning prevailing ambiguity or confusion, to say the least. Define certainly entails is readecuen stipulated for the coordination mechanisms and metropolitan management and the policies that are more consistent ${ }^{3}$.

However, rather than question the vagueness and the actions of local stakeholders and municipalities, should be emphasized the establishment of an incentive with negative and positive effects. The actors Act in this way simply to access and obtain funds tagged or embedded in the metropolitan area. Therefore, the mayors are trying to conform to federal policies. This suggests that the Association of municipal and intermunicipal coordination recently intends to put into practice, or thought, in schemes of the Metropolitan. The consequence is that these mechanisms of management, not only Metropolitan but regional, are bypassing other areas or issues of policy aimed at the promotion and economic partnership, hydraulic policies or the environmental, to name a few. For many municipalities Association and intermunicipal coordination begins to think about metropolitan areas schemes which is of reoriented the associations and intermunicipal coordination thematically, on the one hand,

\footnotetext{
${ }^{3}$ For example in Jalisco, and the effects caused on the city councils of Jalisco is the municipal Presidents of San Miguel el Alto, Tepatitlán, Arandas and San Ignacio Cerro Gordo to signed an agreement in July to form the metropolitan area of Tepatitlán. After the signing, the mayors were enthusiastic about this new metropolitan area, but did so motivated by the advantages of creating them. They said, the benefits consisted of coordinating actions of public security and "take advantage of a special bag that has the Federation for metropolitan areas in the country" (Milenio, 2011/07/10). Its initiative to establish a metropolitan area certainly does not fit the definitions of federal and State authorities; the foregoing shows that San Ignacio Cerro Gordo and the town of Guadalupe Chapel, municipality of Tepatitlán, could form a metropolitan area, but hard to form a metropolitan area with based on the criteria of Conapo-Sedesol, either an area or region based on the law on metropolitan coordination of Jalisco not having 50,000 inhabitants and the head municipality of Tepatitlán remain outside this boundary. In this case if you want to create an area or metropolitan area should go beyond the legal criterion or planning and contemplate the functional aspect or geoeconomics.
} 
and that regionalization policies, both State and federal, have failed, on the other ${ }^{4}$.

As is shown there is a policy matter that seems to be clear. The drawback is that councils are adjusting the governmental coordination and intermunicipal associations in metropolitan terms. This leads to other policy areas to forget as well that there are no financial resources to that Association and intermunicipal coordination will encourage in other subjects. Simply by the fact of obtaining infrastructure and under the speech municipal Presidents of municipalities become poles of development and attract investment to act in this way and not be aware of the implications.

It is true that on the issue of policies and the territory, there is much to discuss; and somehow the criticism of policies of metropolitan areas as a fashion sense so it is necessary to take them cautiously and with a critical tone. This since history tells that in the country have been formulated and implemented policies through watersheds, poles of development, promoting the medium cities, regionalization, to name a few, and have not had the opportunity to have clarity in the course. Despite the above, at the end is perceived that the Metropolitan policy and the management is an issue that is not yet exhausted. It should encourage academic debate for not only conceptual precision but it poured knowledge can integrate more coherent policies and thereby solve the various problems of these urban conglomerates. But to understand the nature and problems of fund management and governance of metropolitan areas it is necessary to bring the problem to the issue of intergovernmental coordination, and this issue will be the question to be addressed in the following paragraphs.

\section{Efforts of Metropolitan Coordination: Institutional Frameworks}

For one thing we need to remember that the federal system denotes a system of political organization of the state. This political system recognizes more fields or orders of Government with various powers, duties and powers in formal terms; and the underlying complexity when they converge or come into conflict, various actors and institutions. Are instituted so complex intergovernmental relations where either the legality and the formal rules of play are important to define the competences and duties, irrespective of the system of political organization; links or mechanisms for coordination and cooperation; mutual support, exchange of actions occurring between two or more instances of Government or bureaucratic dependencies, place the intergovernmental relations as a sociological reality.

However, as this is a system of political organization in which the constitutions recognize certain sovereignty or autonomy to each area of government action or no action, intergovernmental relations require stronger incentives external or contextual so go to work together and shared. Therefore, intergovernmental relations in a federal system concern a complex interaction between rules and actors; and manifest, or not, in processes of coordination, cooperation, collaboration between different areas of Government.

And as subject of agenda and formulation of public policies, the country is being discussed Metropolitan phenomenon as well as various legal and formal mechanisms that make more solid and effective intergovernmental coordination. For example, and at the federal level, in April the Chamber of Deputies, approved a package of reforms in the area of metropolitan areas. Proposals sought that the federal Congress had power to legislate on urban development, management of the territory and metropolitan systems. We also sought to include topics that had to do with municipal participation in national planning and metropolitan development processes; legislate metropolitan coordination and declare metropolitan areas, among other provisions that rule the concurrence between the orders of Government (see Arellano, 2013a: 33-42).

According to this formulation phase various federative entities entered you the challenge of laying a legal enunciation and designing various metropolitan coordination mechanisms. They were the States of Colima, Hidalgo, Jalisco, Morelos, Oaxaca and Zacatecas (see Arellano, 2014a and 2014b).

The legal definitions of the Metropolitan phenomenon of the States of Hidalgo, Morelos and Oaxaca found that they were identical to the social and urban of the metropolitan area of Sedesol, Conapo and Inegi disquisition. If anything in the State of Oaxaca added a demographic question to specify a minimum population of 50,000 people. Therefore, it can be argued that these initial statements remain in urban areas, even though

\footnotetext{
${ }^{4}$ The trend to metropolitan areas remains in territorial policies, is strengthened when Jalisco recently sought to create eight metropolitan areas. The idea of instituting other metropolitan areas — who would be rather metropolis — and add to those of Guadalajara, Puerto Vallarta and Ocotlán, were cases of Ciudad Guzman, Autlan, Lagos de Moreno and La Barca, the latter would be also Interstate since it would settle for the municipality of Briseñas, Michoacan (El Economista, 2012/12/23). In the State of Michoacan also this trend is taking place. So that through the Secretariat of urban development and environment, the entity is has proposed a policy of metropolitan areas. In the year of 2011, and a study and diagnosis, the Michoacan Government recognized that there were five metropolitan areas in the State. In addition to the metropolitan areas of the pity-Pénjamo and Zamora-Jacona accorded Sedesol, Conapo and Inegi, considered another three. They are the metropolitan area of Morelia Metropolitan Lazarus Cardenas-la Union and the metropolitan area of Sahuayo (Suma, 2011).
} 
throughout the legislation the concern may be implicit (Arellano, 2014a and see Table 1).

In contrast, the legal definitions of Metropolitan phenomenon in the States of Colima and Jalisco were closely linked to the issue of intergovernmental coordination. The case of Zacatecas was found at an intermediate level. In its definition of the Metropolitan phenomenon followed the urban tessitura of the problem but limited coordination to the field of planning (Arellano, 2014a, Table 1 and Map 1).

As to the institutional architecture of metropolitan coordination in these States of the Republic can tell that three bodies designed: one political, other technical and other participation or consultation citizen. Of course there are nuances in this general comment. With adjustments and degrees, there are designs in which the logic of coordination goes the State Government to the municipalities: were the cases of Hidalgo, Morelos and Oaxaca. His design involves bodies such as State, federal and municipal course, but the logic of coordination, one could say is, vertical; in the case of Oaxaca is so bureaucratically more variegated. In the end, the Metropolitan phenomenon and the management of these Territories via coordination, as stated, is in a phase of formulation, which does not end up institutionalized, be stable or lasting precisely because there are problems of institutional design (Arellano, 2014b and Table 2).

\section{Conclusions}

It can be concluded emphatically and as a stocktaking exercise that urbanization is a challenge for the country. The urbanization is a social reality with very complex issues that require further intergovernmental cooperation. And therein at least two municipalities are involved. The urbanization is a social and urban reality with very complex problems that require greater intergovernmental cooperation, as at least two municipalities are involved.

The Metropolitan phenomenon manifests itself in many problems of urban, social and economic in the territories where it manifests itself. And federal programs have been designed at the national level and it has been a bag of financial resources. This has conditioned that councils adhere to these guidelines. So that city councils,

\section{Table 1. The legal definition of Metropolitan phenomenon in different state laws.}

\begin{tabular}{|c|c|c|}
\hline Estate & Área(s) urban(s) & Definition \\
\hline Colima & $\begin{array}{c}\text { “Zona } \\
\text { metropolitana” }\end{array}$ & $\begin{array}{c}\text {..., shall include as a metropolitan area, the geographic area belonging to two or more municipalities } \\
\text { bound by the conurbation, by ties of physical, economic and social, that will coordinate to } \\
\text { plan the provision of public services, works of infrastructure and other development actions with } \\
\text { metropolitan vision in short, medium and long term, agreed between independently } \\
\text { of each administration, in coordination with the Government. }\end{array}$ \\
\hline Hidalgo & $\begin{array}{c}\text { “Zona } \\
\text { metropolitana” }\end{array}$ & $\begin{array}{c}\ldots \text { It is the territorial area of dominant influence of a population Center; focused } \\
\text { on the powers of the municipalities and the federal entities in terms of intergovernmental } \\
\text { and interstate coordination for its administration; }\end{array}$ \\
\hline \multirow{2}{*}{ Jalisco } & $\begin{array}{c}\text { “Área } \\
\text { metropolitana” }\end{array}$ & $\begin{array}{l}\text {... is the center of population, geographically delimited, settled in the territory of two } \\
\text { or more municipalities, with a population of when less fifty thousand inhabitants, } \\
\text { officially declared with that character by Decree of the State Congress. }\end{array}$ \\
\hline & $\begin{array}{c}\text { “Región } \\
\text { metropolitana” }\end{array}$ & $\begin{array}{l}\text { It is the geographical delimitation by a metropolitan area and one or more population centers, } \\
\text { geographically close, with trends of growth that bring closer them and socio-economic } \\
\text { relations with it, officially declared with that character by Decree of the State Congress. }\end{array}$ \\
\hline Morelos & $\begin{array}{c}\text { “Zona } \\
\text { metropolitana” }\end{array}$ & $\begin{array}{l}\text {... It is the territorial area of dominant influence of a population Center; focused } \\
\text { on the powers of the municipalities and the federal entities in terms } \\
\text { of intergovernmental and interstate coordination for its administration; (sic) }\end{array}$ \\
\hline Oaxaca & $\begin{array}{c}\text { “Zona } \\
\text { metropolitana” }\end{array}$ & $\begin{array}{l}\text {... It is the territorial space of dominant influence of a population Center, set of two or more municipalities } \\
\text { or territorial demarcations in which lies a city of 50,000 or more inhabitants, whose urban area, } \\
\text { functions and activities beyond the limit of the municipality or demarcation that originally contained it, } \\
\text { incorporating as part of itself or its area of direct influence to neigh boring municipalities } \\
\text { predominantly urban, with which it maintains a high degree of socio-economic integration. }\end{array}$ \\
\hline Zacatecas & $\begin{array}{c}\text { “Zona } \\
\text { metropolitana” }\end{array}$ & $\begin{array}{l}\text {... It is the territorial space between whose population centres there are close economic, } \\
\text { social and cultural links which make it necessary to joint planning and coordination } \\
\text { in the implementation of works, projects and actions for the rational provision of public services. }\end{array}$ \\
\hline
\end{tabular}

Source: Arellano, 2014a. 


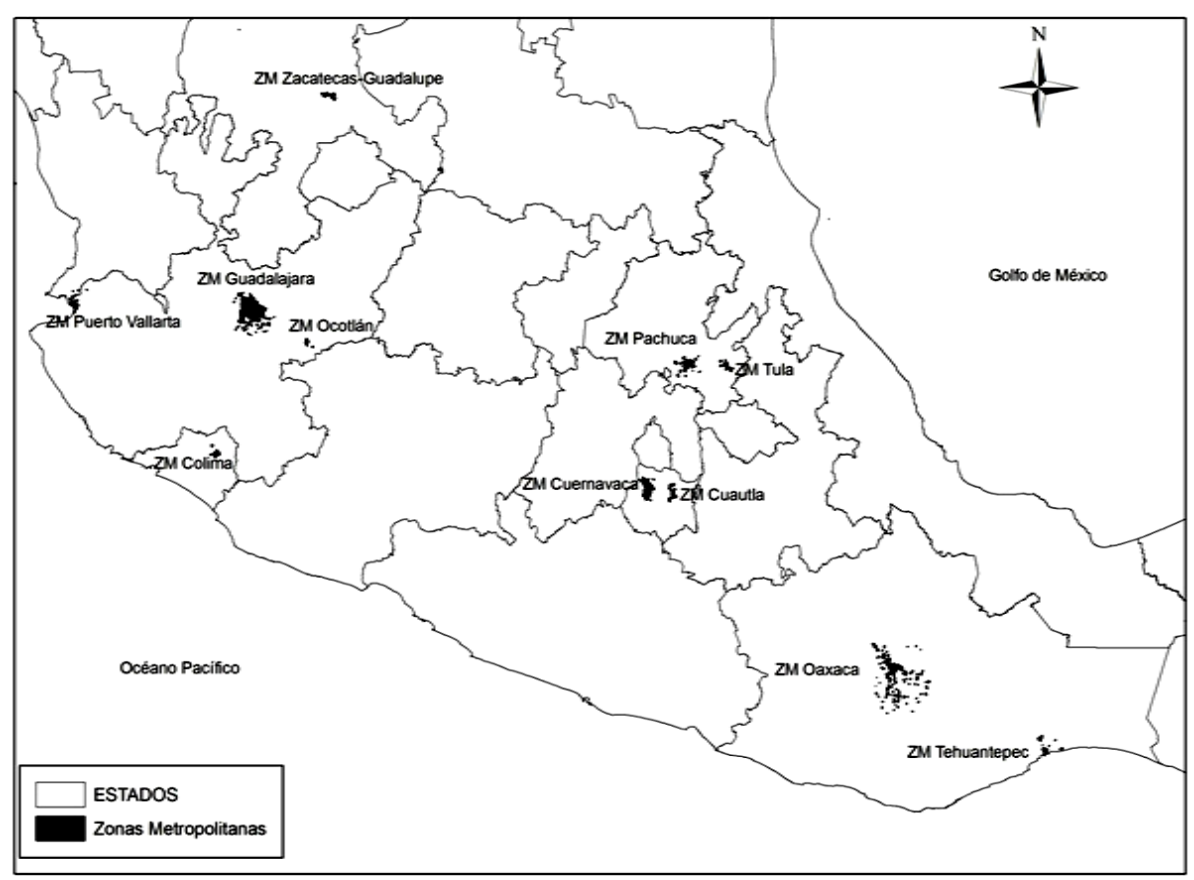

Map 1. Metropolitan areas in the Mexican states with such laws. Source: own.

Table 2. Instances of metropolitan coordination referred to in State laws.

\begin{tabular}{|c|c|c|}
\hline State & Institutions & The instance property \\
\hline \multirow{3}{*}{ Colima } & Metropolitan Development Commission & $\begin{array}{l}\text { It is a body of opinion and decision consisting } \\
\text { of the Governor and municipal authorities }\end{array}$ \\
\hline & Metropolitan Development Institute & $\begin{array}{l}\text { It is a body for consultation, opinion and technical dependent } \\
\text { of the Metropolitan Development Commission. }\end{array}$ \\
\hline & Citizen Metropolitan Council & It is a body for consultation and opinion of the society. \\
\hline \multirow{3}{*}{ Hidalgo } & Council State Metropolitan & $\begin{array}{l}\text { is a body for consultation and opinion involving State } \\
\text { and municipal instances }\end{array}$ \\
\hline & $\begin{array}{c}\text { Coordination of } \\
\text { Development Metropolitana }\end{array}$ & $\begin{array}{l}\text { It is an organ of consultation and opinion, conceived } \\
\text { as a support of the Executive estate. }\end{array}$ \\
\hline & Metropolitan committees & Son unit bodies of opinion and consultation of society \\
\hline \multirow{3}{*}{ Jalisco } & Metropolitan Coordination Board & $\begin{array}{l}\text { Political body and integrated decision by the Governor } \\
\text { and municipal Presidents that make up the metropolitan area. }\end{array}$ \\
\hline & Institute Metropolitan of Planning & Technicalinstance \\
\hline & Citizen Metropolitan Council & Instance of consultation and citizen participation. \\
\hline \multirow{3}{*}{ Morelos } & Council for the Metropolitan Development & Hierarchical query of the metropolitan planning body. \\
\hline & Technical Committee of the trust & Instance empowered to authorize resources. \\
\hline & Sub-Committee on evaluation of projects & Technical body to exercise resources. \\
\hline \multirow{4}{*}{ Oаxaca } & Council for the Metropolitan Development & Stateintergovernmentalcoordinatingbody. \\
\hline & $\begin{array}{l}\text { Institute of metropolitan planning for the } \\
\text { sustainable development of the State of Oaxaca }\end{array}$ & $\begin{array}{l}\text { Technical body for inter-municipal consensus of the } \\
\text { jurisdicionados municipalities in the metropolitan area. }\end{array}$ \\
\hline & Honorary Council Metropolitan of citizen participation & Organ of consultation and consensus with civil society. \\
\hline & Committee on consensus-building and sectoral proposal & $\begin{array}{l}\text { Technical and support of the tip fees metropolitans } \\
\text { of citizen participation body }\end{array}$ \\
\hline \multirow[b]{2}{*}{ Zacatecas } & Metropolitan Development Council & $\begin{array}{l}\text { Instance of consultation, opinion and consensus coordinated } \\
\text { the implementation of plans and projects. }\end{array}$ \\
\hline & Metropolitan Development Fund & $\begin{array}{l}\text { It is the Monetary Fund consisting of resources } \\
\text { to finance the implementation of studies, programmes, } \\
\text { projects, actions and works of metropolitan character. }\end{array}$ \\
\hline
\end{tabular}

Source: Arellano, 2014b. 
and the country's municipality variety, having no institutional and financial capacities, have to deal with metropolitan problems, not only to consider vision and will, and have a technical basis, but to consider that innovation practices and political work are part of the intergovernmental coordination and inter-municipal associations. The real change lies in innnovar political practices and political work are framed in the intergovernmental coordination and intermunicipal associations. The problem of metropolitan governance and management is then political and intergovernmental relations for decision-making.

\section{References}

Arellano, A. (2014a). La definición legal del fenómeno metropolitano. Opinión Jurídica, 13, in press.

Arellano, A. (2014b). La coordinación metropolitana en el ámbito subnacional mexicano: un análisis institucional. Documentos y Aportes en Administración Pública y Gestión Estatal, 14, in press.

Arellano, A. (2013). La gestión metropolitan. Casos y experiencias de diseño institucional. México: UNAM-IIJ-Jalisco.

Arellano A., \& Ortiz, I. (cords.) (2013). Coordinación y gestión metropolitana en Jalisco, Puerto Vallarta. CUCOSTAUniversidad de Guadalajara.

Arias, R. (coord.) (2013). Coordinación metropolitana y gestión municipal, Zapopan, El Colegio de Jalisco.

Garrocho, C. (2012). Estructura funcional de redes de ciudades. Zinacantepec, Mexico, El Colegio Mexiquense-Naciones Unidas-Conapo.

Sedesol, Conapo and Inegi (2010). La delimitación de zonas metropolitanas. Aguascalientes, Sedesol-Conapo-Inegi. Sedesol, Conapo and Inegi (2007). La delimitación de zonas metropolitanas. Aguascalientes, Sedesol-Conapo-Inegi.

Suma (2011). Áreas metropolitanas del Estado de Michoacán. October. 
Scientific Research Publishing (SCIRP) is one of the largest Open Access journal publishers. It is currently publishing more than 200 open access, online, peer-reviewed journals covering a wide range of academic disciplines. SCIRP serves the worldwide academic communities and contributes to the progress and application of science with its publication.

Other selected journals from SCIRP are listed as below. Submit your manuscript to us via either submit@scirp.org or Online Submission Portal.
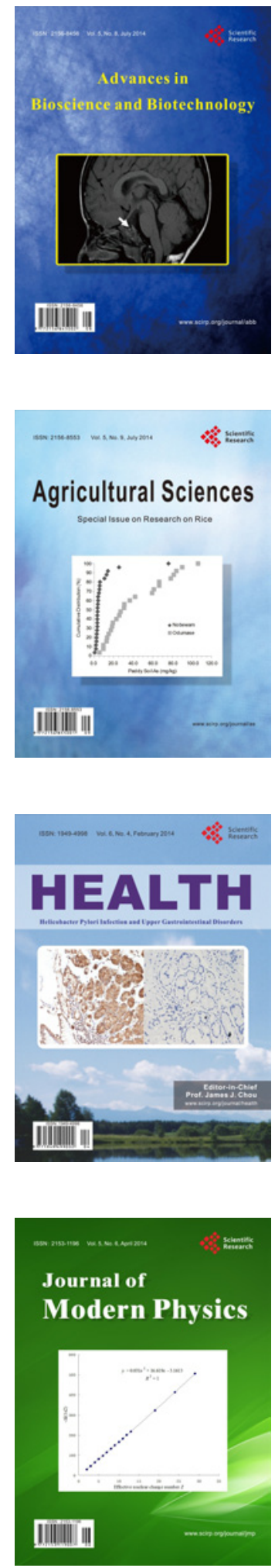
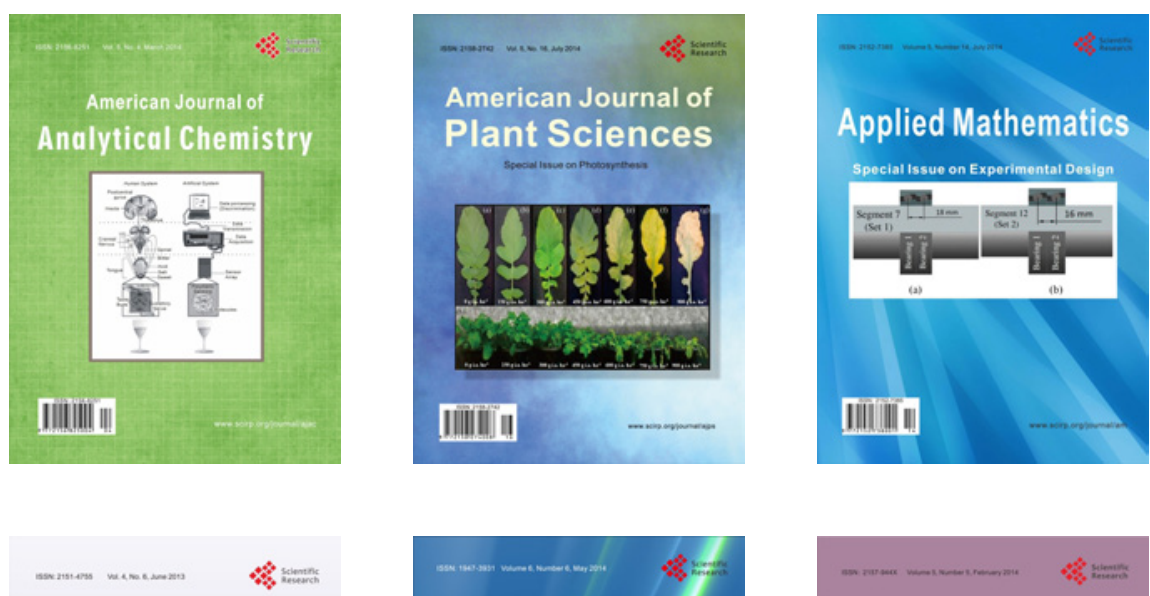

Creative Education
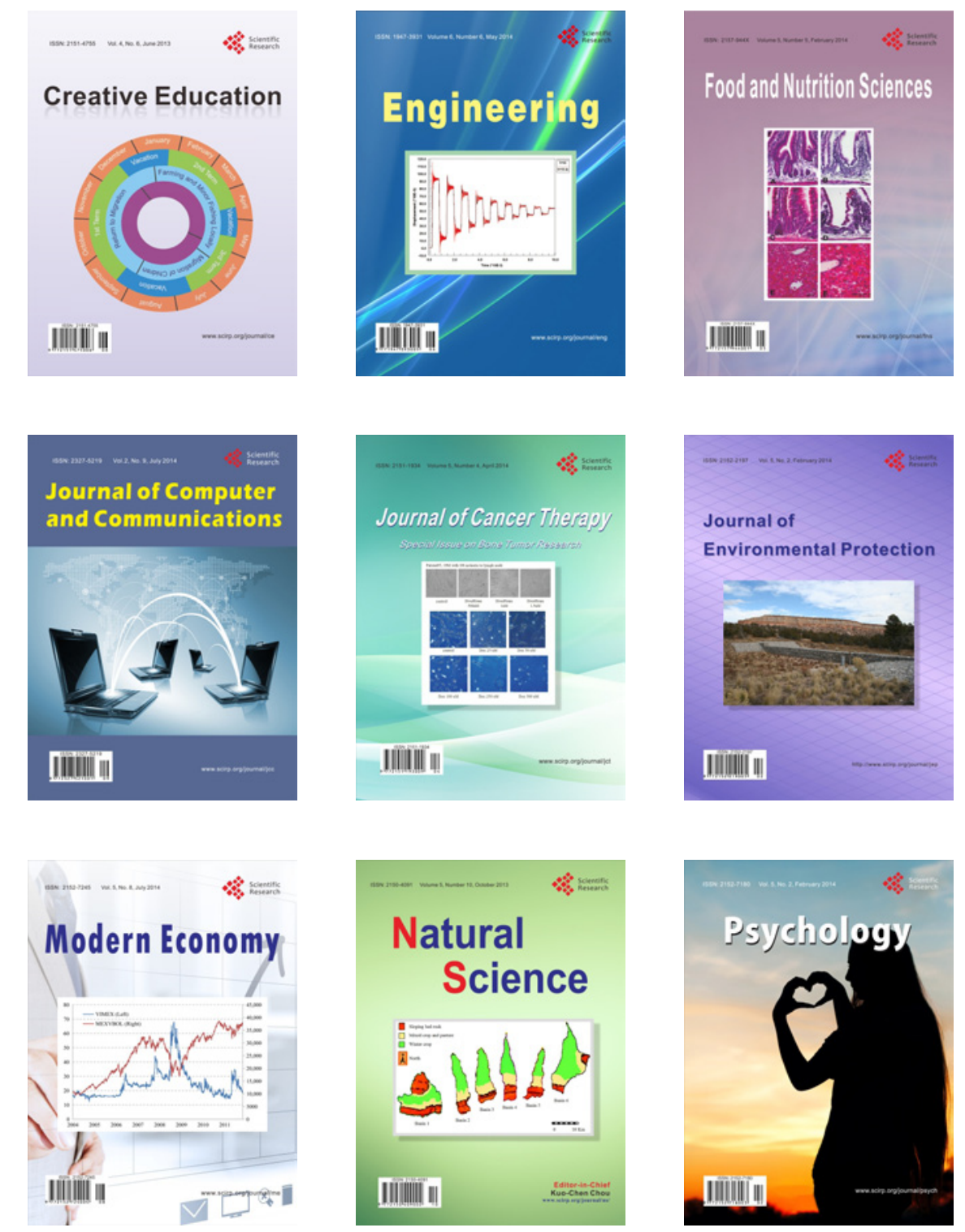